\title{
Changes in Customer Preferences for Furniture in Slovenia
}

\section{Promjene sklonosti kupaca namještaja u Sloveniji}

\author{
Original scientific paper • Izvorni znanstveni rad \\ Received-prispjelo: 20. 10. 2019. \\ Accepted-prihvaćeno: 28. 4. 2020. \\ UDK: $630 * 72$ \\ https://doi.org/10.5552/drvind.2020.1967
}

\author{
(C) 2020 by the author(s). \\ Licensee Faculty of Forestry, University of Zagreb. \\ This article is an open access article distributed \\ under the terms and conditions of the \\ Creative Commons Attribution (CC BY 4.0) license.
}

\begin{abstract}
In the last decade, the Slovenian furniture industry market has experienced a number of changes, especially with the arrival of new retailers on the market. The situation is such that furniture manufacturers and retailers are still trying to determine the best ways to adjust to new customer demands. A well known thing is that customer satisfaction is the key component for the success of the business. In order for companies to be more successful, it is important to get better insight into customers'needs and wants. In line with this, the purpose of this study, which compare the surveys conducted in 2010 and 2019, was to observe and analyse changes in the preferences of customers for furniture: materials, attributes, and styles when deciding on new furniture in Slovenia. The results of this research showed that customers' preferences for furniture materials have changed in the last decade. Similarly, the factors that influence their purchase decisions when buying interior and exterior furniture have changed as well. It was found that wood was widely preferred as a furniture material among the respondents in both years studied.
\end{abstract}

Keywords: wooden furniture; customer preferences; survey; Slovenian market

SAŽETAK • U posljednjem desetljeću slovensko je tržište namještaja doživjelo mnoge promjene, posebice ulaskom stranih trgovaca. Stoga proizvođači namještaja i trgovci i dalje pokušavaju odrediti najbolje načine prilagodbe novim zahtjevima kupaca. Općenito je poznato da je zadovoljstvo kupaca ključna komponenta za uspjeh poslovanja. Kako bi tvrtke bile uspješne, važno je imati što bolji uvid u potrebe i želje kupaca. U skladu s tim, cilj ovog istraživanja, koje uspoređuju ankete provedene 2010. i 2019., bila je usporedba i analiza promjena sklonosti kupaca pri odabiru i kupnji namještaja, i to u smislu materijala, svojstava i stila. Rezultati provedenog istraživanja pokazali su da su se sklonosti ispitanika u odabiru materijala namještaja u posljednjem desetljeću promijenile. Osim toga, promijenili su se i činitelji koji utječu na njihove odluke pri kupnji namještaja za vanjsku ili unutarnju upotrebu. Ispitivanja su pokazala da je drvo 2010. bio vrlo poželjan materijal za izradu namještaj, a to je i danas.

Ključne riječi: namještaj od drva; sklonosti kupaca; anketa; slovensko tržište

\footnotetext{
${ }^{1}$ Authors are senior assistant professors at University of Ljubljana, Biotechnical Faculty, Department of Wood Science and Technology, Ljubljana, Republic of Slovenia.

${ }^{2}$ Authors are assistant professors at Technical University in Zvolen, Faculty of Wood Sciences and Technology, Department of Marketing, Trade and World Forestry, Zvolen, Republic of Slovakia.

${ }^{3}$ Authors are assistant professor and postdoctoral researcher at University of Zagreb, Faculty of Forestry, Wood Technology Department, Zagreb, Republic of Croatia.
} 


\section{INTRODUCTION}

\section{UVOD}

The benefits derived from wood are the key factors in the competition between wood and non-wood products. A wood product is composed of various attributes, and the consumers' choice is guided by their quality. With regard to the product, the main challenge is to get consumers' attention, catch their preferences and buying habits. The aim of this study was thus to better understand consumer preferences and buying habits with regard to furniture and to observe the changes in the preferences of Slovenian costumers.

An important body of literature focuses on consumer preferences in furniture markets and the competition between wood and non-wood products. The typical characteristics consumers assign to wood materials have been studied by several researchers (Pakarinen and Asikainen, 2001; Bowe and Bumgardner, 2004; Scholz and Decker, 2007; Kaputa et al., 2018). Attempts have also been made to map how the properties of wood are related to preferences (Nyrud et al., 2008). The effects of background and profession on preferences have also been investigated (Marchal and Mothe, 1994; Roos and Nyrud, 2008). However, a study of how wood as a material is perceived and characterised in relation to alternative wood-based materials, such as panels and woodbased composites, remains to be conducted. Jonsson et al. (2008) identified the attributes and associations that people use to describe different types of wood materials, and explored how they relate to preferences.

The wood used for furniture production has a strong impact on consumer's preferences for the product as a whole. Costa et al. (2011) confirmed that the quality levels of wood product attributes are endogenous variables, and depend on the level of information a consumer has in the buying decision process. According to Scholz and Decker (2007), the wood species used in manufacturing not only affects the material appearance, but also the preferences for seemingly unrelated attributes, like style and design. An Sheng Lee (2010) found that the features of furniture product designs and consumer satisfaction have positive correlations in a Taiwanese sample. The feature of functional design mostly influences consumers' satisfaction when making decisions to buy furniture products. Bumgardner et al. (2007) evaluated consumer preferences for six domestic wood species. Similar research by Nichols and Bumgardner (2007) evaluated how age, gender and income influence consumer preferences for the species used in household furniture products, and they found that age and income were statistically significant in this context (with a stronger effect of age), while gender was not significant.

Numerous studies have measured consumer attitudes toward wooden furniture. Buehlmann and Shuler (2009) analysed the development and opportunities in the US furniture market. Later on, Buehlmann cooperated with Lihra and Graf (2012) and they measured, via a choice-based conjoint analysis, the value that US consumers assign to the availability of customisation when buying furniture. They found that, roughly $50 \%$ of consumers' product choice is driven by price, $20 \%$ by product customisation, $20 \%$ by delivery time, and $10 \%$ by the time needed to customise the product. Ponder (2013) compared and determined the extent to which attitudes and behaviour towards home furniture have changed over a five-year period. In Finland, Pakarinen and Asikainen (2001) examined the use of wood as a material for furniture, aiming to highlight the important attributes that consumers consider when selecting a piece of furniture. Based on their results, quality and design were ranked as the most important attributes. Troian (2011) defined the factors that influence consumers' choice of a product and analysed the furniture preferences in Italy and in different cultural environments. She concluded that, despite the fact of high-speed globalization, consumers from different geographical zones do vary their behaviour in the different cultural contexts. This could create a barrier to rapid entry in foreign markets. Thus, furniture manufacturers have to deal with a deeper understanding of local cultures and their influence upon purchase behaviour.

Other studies have measured consumer attitudes towards eco-labelled forest products (Forsyth et al., 1999; Ozanne and Smith, 1996; Ozanne and Vlosky, 1997; Vlosky et al., 1999). Generally, these studies found that consumers hold favourable attitudes to certified products, and would like to purchase them. They are willing to pay more and they prefer certified to uncertified forest products. However, for most respondents, product attributes other than eco-labelling are more important when forming preferences (for example, price). Research done by Teisl (2003) found that consumer demand and willingness to pay for certified products are contingent on the information provided on an ecolabel. Consumers prefer ecolabels with detailed information about the environmental benefits associated with eco-labelled products.

The issue of the consumer preferences for furniture was also the subject of several studies in Slovakia and Croatia (Kaputa and Supin, 2010; Kaputa, 2013; Kaputa et al., 2018). In addition, several authors (Oblak and Jost, 2011; Palus et al., 2014; Palus and Mat'ova, 2009) have dealt with the awareness of endusers about the labels used by forest certification schemes, which allow to track the origin of wood. Several conclusions can be drawn from these earlier studies: the most relevant purchase decision factors are quality, price and design of furniture. The most preferred is modern style furniture. The decision to buy a certain piece of furniture most frequently arises in a store, followed by when using a catalogue or the internet, and is mostly based on a compromise between the man and woman in a household (Kaputa and Supin, 2010). Over $40 \%$ of respondents are aware of the existence of labelled products, either spontaneously or when prompted, but only $5 \%$ of them understand the exact or approximate meaning of the labels. Most of consumers, who are aware of labels and also read them, are between the ages of 41-60 and represent either middle or higher income classes (Palus et al., 2014). 


\section{MATERIALS AND METHODS}

\section{MATERIJALI I METODE}

The questionnaire was developed based on previous research results and using the existing literature. The first survey, held in November 2010, was implemented during the furniture fair Ambient in Ljubljana. There were 300 surveyed respondents and the results have not been published. The second survey was done in April 2019 using a web platform (www.1ka.si). There were 128 valid filled-in questionnaires, out of 218 clicks on the page where the survey was published. A link to the electronic version of the questionnaire was distributed by students and researchers using social networks and e-mail addresses. Thus, a non-probability snowball sampling method was used to spread the questionnaire. Nonprobability sampling, used to cover as many respondents as possible, could also be called purposive sampling, as Dillon et al. (1990) stated, because certain segments of the target population were intentionally overrepresented in the sample (such as age categories - any respondents under 18 years old).

The questionnaire consisted of two parts, where the first part dealt with demographic characteristics such as gender, achieved education level (primary school, high school, and university), and the age categories.

The questions in the second part were concerned with a decision-making process when purchasing furniture, and specific consumer preferences for:

- material: solid wood, wood composites, plastic, metal, glass, and combination of materials (requested for both - interior and exterior furniture)

- furniture attributes (price, manufacturing quality, design, environmental attributes, country of origin, warranty, colour, brand, and safety), and

- furniture styles (rustic, modern, futuristic, and retro).

The respondents answered using a Likert-type scale, based on the observation in Churchill (1979) that no single item is likely to provide a perfect representation of the general idea. The scales revealed the level of agreement with various statements: 1 (definitely no), 2 (somewhat no), 3 (neither yes nor no/indifferent), 4 (somewhat yes), and 5 (definitely yes). For interpretation purposes of the frequency analysis results, we combined the answers "Definitely Yes" and "Somewhat Yes" into one indicating a positive attitude towards a certain kind of material. The same approach was applied in case of the answers "Definitely No" and "Somewhat No", which indicated a negative attitude. The indifferent attitude stayed as it was.

The statistical software SPSS PASW Statistics 18 and STATISTICA 12 for MS Windows were used for the data analyses, as well as Microsoft Excel. First, frequency analysis and cross-tabulation were used to determine the basic relationships among the answers. Pearson's chi-squared test of independence (at an $\alpha=$ 0.05 significance level) was used to assess the significance of the frequency differences among the demographic characteristics.
The null hypothesis was stated to test the statistical significance of differences in preferences between the two surveys (at a $95 \%$ confidence interval). A nonparametric Mann-Whitney U test for two independent samples was employed, since the test of normality revealed that the data were not normally distributed.

\section{RESULTS AND DISCUSSION} 3. REZULTATI I RASPRAVA

\subsection{Demographic analyses of samples}

3.1. Demografska analiza uzoraka

First, the significance of differences between the samples of the two surveyed years was analysed. There are no statistically significant differences in frequencies (Pearson's chi-square test at $\alpha=0.05$ significance level) between the respondents from the two years in terms of gender. On other hand, there are significant differences between the samples of respondents regarding the frequencies of achieved education $\left(\chi^{2}=\right.$ 58.670; $\mathrm{p}<0.05)$ as well as between the frequencies of the compared age categories $\left(\chi^{2}=25.613 ; \mathrm{p}<0.05\right)$. Both samples contain a high share of respondents of a young age - between 18 and 30 years old (over $40 \%$ in 2010 and over $33 \%$ in 2019). In 2019, the sample was composed of respondents with a higher share of older age categories and with a higher level of education, where fewer had finished high school and more completed bachelor's and postgraduate degrees.

\subsection{Consumer preferences regarding furniture} material

3.2. Sklonosti kupaca u smislu odabira materijala za namještaj

As shown in Table 1, the consumer preferences regarding the material for interior furniture did not change in the scope of the observed years, except for furniture made of plastic. On the other hand, compared preferences for exterior furniture were only similar in case of furniture made of glass. All the other preferences for the exterior furniture material were significantly different at $\alpha=0.05$ significance level between the observed years.

The marginal answers are clear from Figure 1, which introduces especially high shares of the 'definitely' positive attitudes towards interior furniture made of solid wood (reaching almost $60 \%$ of respondents in both years) and high shares of the 'definitely' negative attitudes towards interior furniture made of plastic (ranging from around $33 \%$ in 2010 up to $46 \%$ in 2019).

Overall, the most preferred material for interior furniture was solid wood, as stated by $74 \%$ of the respondents in 2010 and $81 \%$ in 2019 (Figure 1). The second option is wood composite, followed by a combination of materials, glass, metal and finally plastic. The biggest fall in preferences (and statistically significant: Mann-Whitney $U=15424.0, p=0.001$ ) between 2010 and 2019 was observed in case of plastic. This fact could be related to an anti-plastic campaign in the EU and worldwide (Barrett, 2019). 
Table 1 Mann-Whitney U test of consumer preferences regarding furniture material

Tablica 1. Mann-Whitneyjev U-test sklonosti kupaca u odabiru materijala za namještaj

\begin{tabular}{|l|l|c|c|}
\hline \multirow{5}{*}{$\begin{array}{c}\text { Furniture for interior use } \\
\text { Namještaj za unutarnju } \\
\text { uporabu }\end{array}$} & $\begin{array}{c}\text { Furniture material } \\
\text { Materijal za namještaj }\end{array}$ & $\begin{array}{c}\text { Mann-Whitney U } \\
\text { Mann-Whitneyjev U-test }\end{array}$ & $\begin{array}{c}\text { Asymp. sig. (2-tailed) } \\
\text { Asimptotska značajnost } \\
\text { (dvosmjerni test) }\end{array}$ \\
\cline { 2 - 4 } & Wood (solid) / masivno drvo & 18313.0 & 0.397 \\
\cline { 2 - 4 } & Wood composite / drvni kompozit & 18153.0 & 0.351 \\
\cline { 2 - 4 } & Plastic / plastika & 15424.0 & $\mathbf{0 . 0 0 1}$ \\
\cline { 2 - 4 } & Metal / metal & 17475.0 & 0.127 \\
\cline { 2 - 4 } & $\begin{array}{l}\text { Glass / staklo } \\
\text { kombination of materials }\end{array}$ & 17155.0 & 0.070 \\
\hline \multirow{5}{*}{$\begin{array}{l}\text { Furniture for exterior use } \\
\text { Namještaj za vanjsku uporabu }\end{array}$} & Wood (solid) / masivno drvo & 19142.5 & 0.959 \\
\cline { 2 - 4 } & Wood composite / drvni kompozit & 15398.0 & $\mathbf{0 . 0 0 0}$ \\
\cline { 2 - 4 } & Plastic / plastika & 14060.5 & $\mathbf{0 . 0 0 0}$ \\
\cline { 2 - 4 } & Metal / metal & 15404.0 & $\mathbf{0 . 0 0 0}$ \\
\cline { 2 - 4 } & Glass / staklo & 18832.5 & 0.747 \\
\cline { 2 - 4 } & $\begin{array}{l}\text { Combination of materials } \\
\text { kombinacija materijala }\end{array}$ & 16933.5 & $\mathbf{0 . 0 4 6}$ \\
\hline
\end{tabular}

Statistical significance at 0.05 level / statistička značajnost na razini od 0,05

$n=300$ participants in 2010 and $n=128$ participants in $2019 / n=300$ ispitanika $u$ 2010.; $n=128$ ispitanika $u 2019$.

The results showed that solid wood was the most preferred material for exterior furniture (preferred by $60 \%$ of respondents), although it scores $20 \%$ less in 2019 mostly due to the risen share of indifferent attitudes (Figure 2). The second highest ranked material for exterior furniture was a combination of materials, which gained $10 \%$ from 2010 to 2019 (from $45 \%$ up to $55 \%$ ). This might be related to the development of "new" combinations of materials in the last decade. In contrast, traditional wood composites are not so suitable for exterior use, and this was recognised by the respondents as more than $50 \%$ of them expressed a negative attitude to this material.

Metal became more favourable within the sample of respondents in 2019, where a considerably higher share expressed a positive attitude, while at the same time the share of negative attitude dropped by a similar rate (around $10 \%$ ) - similar as in the case of furniture made of plastic material. Preferences for furniture made of glass have maintained the same attitudes.

\subsection{Furniture attributes \\ 3.3. Obilježja namještaja}

As expected, the most important furniture attribute (of all analysed) is manufacturing quality, as almost all the respondents in $2019(97 \%)$ marked quality as a factor influencing their purchase decision (Figure 3). The design of products has become more important for customers over the years, as the share of respondents with a positive attitude increased from $71 \%$ up to 91 $\%$, and it is the second most important attribute in 2019. In general, the high shares of positive (more than

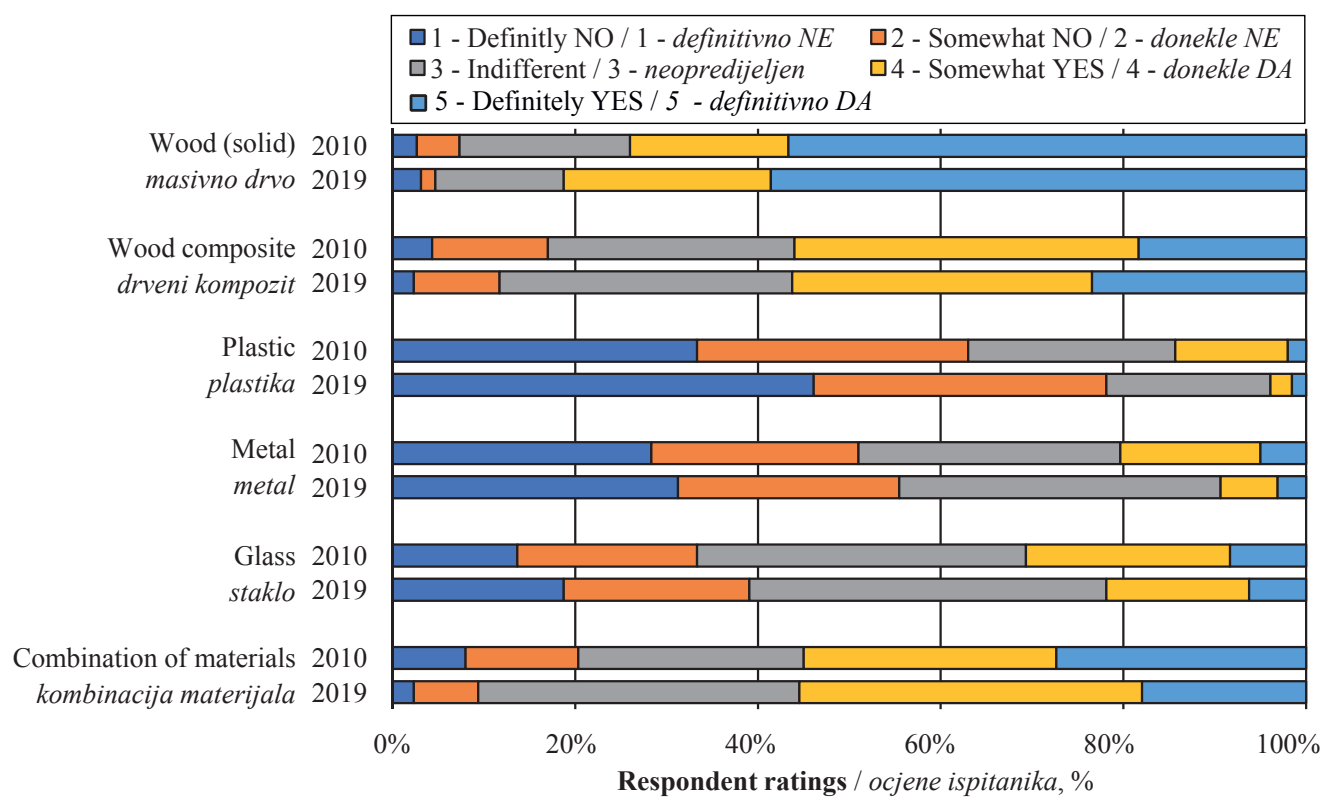

Figure 1 Preferences towards the material used for furniture for interior use

Slika 1. Sklonosti potrošača materijalima za izradu namještaja u interijeru 


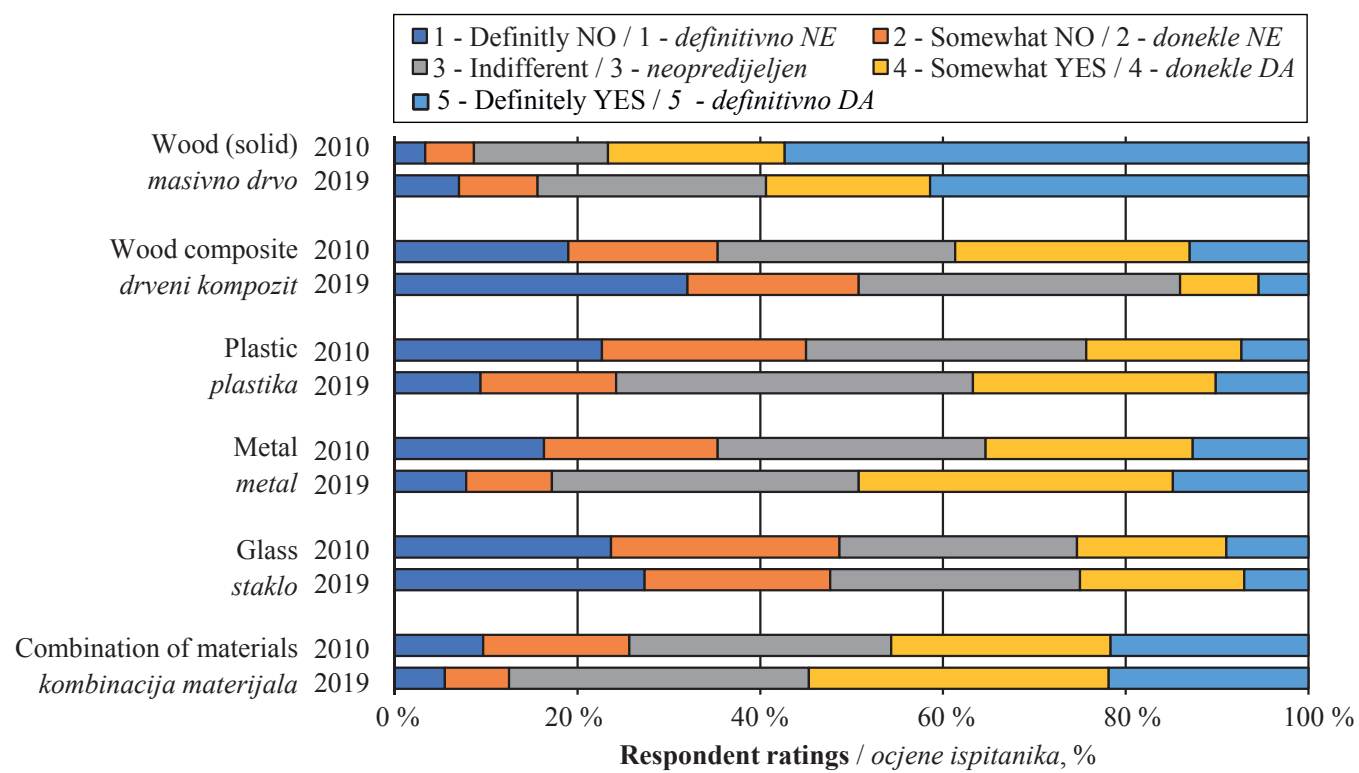

Figure 2 Preferences towards the material used for furniture for exterior use (2010 vs 2019)

Slika 2. Sklonosti potrošača materijalima za izradu namještaja u eksterijeru (usporedba: 2010. i 2019.)

$70 \%$ ) attitudes for quality, design, colour, price and safety indicated that these factors are of a great importance among respondents. Similar findings were reported in previous studies carried out in Slovenia (Oblak et al., 2017, 2009), where the authors found that quality and design were the most relevant factors in purchase decisions. Quality was also recognised as the most important factor in other regions - Croatia and Slovakia (Motik et al., 2004).

The lowest importance was observed in case of country of origin and brand. Moreover, in 2019, preferences for brand even dropped (compared to 2010) at the level of around $20 \%$, while negative attitudes in- creased. On the other hand, the share of respondents whose purchase decision is influenced by environmental attributes and safety increased considerably from 2010 to 2019 up to the level of $54 \%$ (environmental attributes) and over $72 \%$ (safety), respectively, and simultaneously, the share of respondents who are not influenced by these factors decreased.

Respondents were also asked about their preferences for furniture style. The most preferred style in both years was modern style, with $72 \%$ of positive attitudes in 2010 and $66 \%$ in 2019 (the change was statistically significant: Mann-Whitney $U=16675.5, p=$ 0.023). According to Kaputa et al. (2018), the modern



Figure 3 Factors influencing purchase decision to buy furniture (2010 vs 2019)

Slika 3. Činitelji koji utječu na odluku o kupnji namještaja (usporedba: 2010. i 2019.) 
style furniture is also a first choice for the majority of consumers in Slovakia and Croatia. We observed a decrease in the preference for the futuristic style, with just $11 \%$ of positive attitudes and $58 \%$ of negative ones in 2019. Other preferences (for rustic and retro style) has not changed over time and stayed around $30 \%$.

\subsection{Source of information when deciding to buy a piece of furniture}

3.4. Izvori informacija pri odluci o kupnji namještaja

Figure 4 introduces distribution of consumers' responses about ways how or where a purchase decision is made. The results show that a store is the most frequent place. Moreover, the share of consumers whose decision to buy a piece of furniture is made in a store increased (statistically significant: Mann-Whitney $U=15251.5, p=0.004$ ) by $17 \%$ between the years observed, since $59 \%$ of respondents marked this option in 2010 and up to $76 \%$ in 2019. The increase in the use of the internet as a source was also statistically significant (Mann-Whitney $U=16701.5, p=0.028-$ increased by $9 \%$ ) and in 2019 it even reached the level of decisions made in stores in 2010 (Figure 4). Internet became the most popular source of information in all fields, but results indicated that costumers still want to see and touch furniture before making a purchase decision. Oblak et al. (2009) and Perić et al. (2015) also reported that furniture stores were the most preferred source of information in Slovenia and Croatia.

The importance of fairs and exhibitions fell from $40 \%$ in 2010 to $30 \%$ in 2019 (the change was statistically significant; Mann-Whitney $U=15861.0, p=$ $0.003)$. Such decrease in popularity is also reflected in the decline of the number of furniture companies that were present at the main furniture fair in Slovenia Ambient in Ljubljana. In 2010, 83 furniture companies were present at the fair, while in 2018 this number fell to 23 (GR, 2018). The importance of offline advertisements (TV, radio or print) also decreased. Offline ad- vertisement seems to be the least important, as less than $20 \%$ of consumers marked it as relevant for their purchase decision.

In addition, we found out that $84 \%$ of the decisions to purchase furniture in 2019 were based on a compromise between both partners living in a household. Women most likely decide about design and colour, while men decide about the quality. Just $10 \%$ stated that only the female partner decides, while only $6 \%$ said only the male partner does. Based on these findings, we suggest that manufacturers and sellers should aim their marketing communication at women with emphasis on design and colour attributes of furniture.

\section{CONCLUSIONS \\ 4. ZAKLJUČAK}

The results of this study show that customer preferences changed in the years studied - 2010 and 2019. The most preferred material for interior and exterior furniture is solid wood, and over time it has gained some popularity for interior use and lost some for exterior use. For inside use, the second and the third most preferred materials for furniture were wood composites and a combination of materials, with similar preferences in both years observed, while other materials were less popular. On the other hand, combination of materials was the second preferred in case of exterior furniture, while wood composites were the least favoured. All the examined furniture attributes gained in importance with regard to purchase decisions from 2010 to 2019, except for the price, where no change was observed. The most important factor was the quality of the product, followed by design and colour, while country of origin and brand were the factors with the smallest impact on purchase decisions.

Findings about the least importance of a brand are interesting since many companies are keen to build

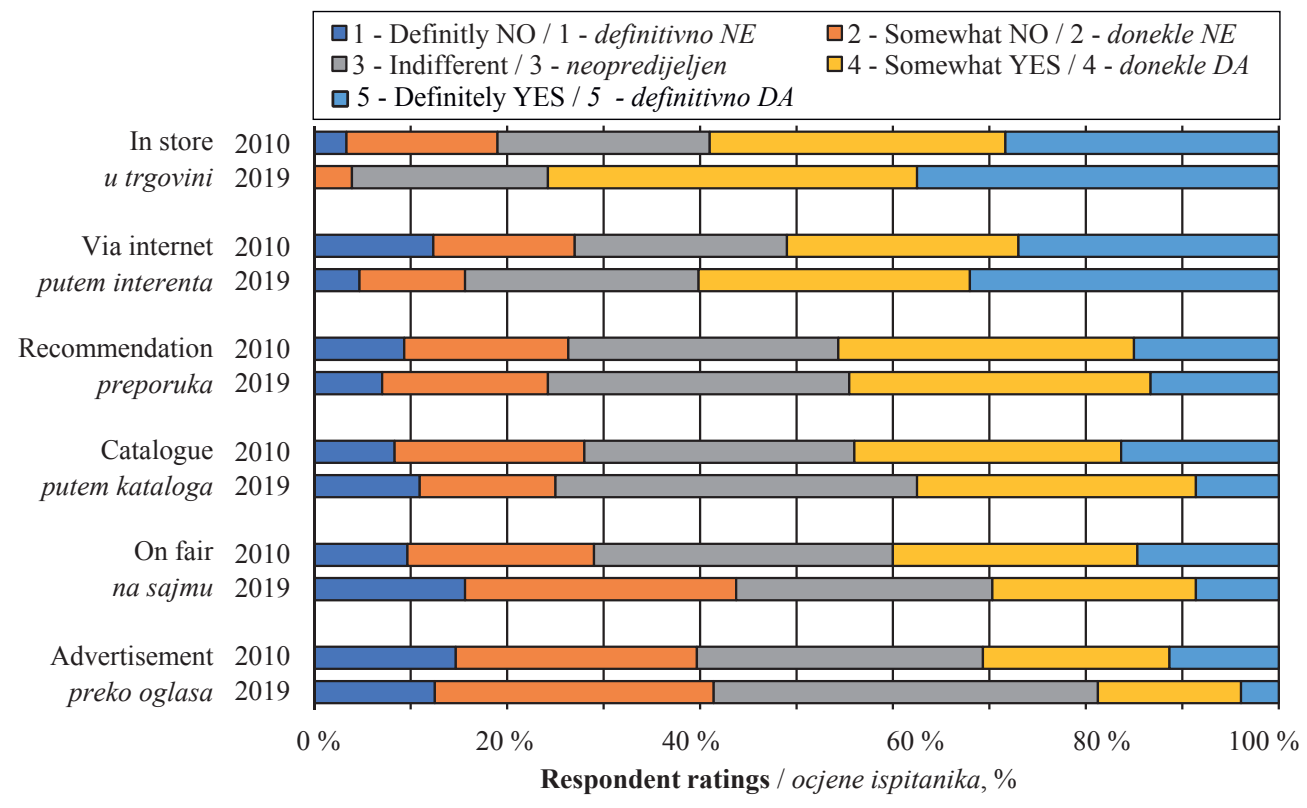

Figure 4 The ways how/where purchase decision to buy a piece of furniture is made (2010 vs 2019)

Slika 4. Kako i gdje kupci donose odluke o kupnji namještaja (usporedba: 2010. i 2019.) 
their image via branding as a major marketing strategy. The same finding about a brand also comes from the study revealing consumers' preferences for furniture in Slovakia and Croatia (Kaputa et al., 2018). It is a challenge for further research to reveal if this is a phenomenon of the regional furniture market or it is caused by overall change of consumers' preferences. Considering also the fact of increasing importance of factors such as environmental attributes, we would like to introduce here the statement of John Grant (2012) that post-brand period has arrived.

It was found that a store is the most frequent place where a purchase decision is made. The second most frequent option is that such decision is made online (via internet). Tools of an offline advertisement (e.g. TV or newspapers) were the least important promotional channels for furniture.

The limitation of this study is the used sampling technique (snowball sampling) in both investigated years. In that case, the samples did not represent the population and thus the results cannot describe the entire population. The next limitation is the demographic composition of the samples with an unusually high share of young people (in both 2010 and 2019). Further, there are significant differences between the two samples of respondents regarding their education and age categories.

\section{Acknowledgements - Zahvala}

The authors acknowledge the financial support this study received from the Slovenian Research Agency (research core funding No. P4-0015). The authors would also like to thank the Scientific Grant Agency of the Ministry of Education, Science, Research and Sport of the Slovak Republic and the Slovak Academy of Sciences, grant number 1/0666/19 "Determination of the development of a wood-based bioeconomy".

\section{REFERENCES}

5. LITERATURA

1. Lee, A. S., 2010: A Study on Predicting Consumers' Satisfaction Based on the Features of Furniture Product Designs. International Journal of Organizational Innovation $2,138-160$

2. Barrett, A., 2019: WWF Launch Anti-Plastic Campaign. Bioplastics News (online). https://bioplasticsnews. com/2019/06/14/wwf-launch-anti-plastic-campaign/ (Accessed Sep. 17, 2019).

3. Bowe, S. A.; Bumgardner, M. S., 2004: Species selection in secondary wood products: Perspectives from different consumers. Wood and Fiber Science, 36: 319-328.

4. Buehlmann, U.; Schuler, A., 2009: The U.S. household furniture industry: Status and opportunities. Forest Products Journal 59.

5. Bumgardner, M.; Nicholls, D.; Donovan, G., 2007: Effects of species information and furniture price on consumer preferences for selected woods. Wood and Fiber Science, 39 (1): 71-81.

6. Costa, S.; Garcia, S.; Ibanez, L., 2011: Do Taste and Quality Perception Influence Consumer Preferences for Wood? An Econometric Model with Latent Variables. Forest science, 57 (2): 89-101.

https://doi.org/10.1093/forestscience/57.2.89.
7. Dillon, W. R., 1990: Marketing research in a marketing environment, $2^{\text {nd }}$ edition. Homewood, IL: Irwin.

8. Forsyth, K.; Haley, D.; Kozak, R., 1999: Will consumers pay more for certified wood products. Journal of Forestry, 97: 18-22.

9. ***GR, 2018. Sejemski katalog 2018. (online). http:// www.pohistveni-sejem.si/za-obiskovalce/2796. http:// www.pohistveni-sejem.si/za-obiskovalce/2796 (Accessed Sep. 21, 2019).

10. Grant, J., 2012: The Green Marketing Manifesto (online). https://www.wiley.com/en-si/The+Green+Marke ting+Manifesto-p-9780470687314 (Accessed Mar. 30, 2020).

11. Jonsson, O.; Lindberg, S.; Roos, A.; Hugosson, M.; Lindström, M., 2008: Consumer Perceptions and Preferences on Solid Wood, Wood-Based Panels, and Composites: A Repertory Grid Study. Wood and Fiber Science, 40: 663678.

12. Kaputa, V., 2013: Trh a environmentálne atribúty výrobkov z dreva. Technical University in Zvolen.

13. Kaputa, V.; Pirc Barčić, A.; Mat’ová, H.; Motik, D., 2018: Consumer Preferences for Wooden Furniture in Croatia and Slovakia. BioResources, 13: 6280-6299. http://dx.doi.org/10.15376/biores.13.3.6280-6299.

14. Kaputa, V.; Supin, M., 2010: Consumer preferences for furniture. In: Proceeding of International Conference WoodEMA. Vyhne, Slovakia, pp. 81-90.

15. Lihra, T.; Buehlmann, U.; Graf, R., 2012: Customer preferences for customized household furniture. Journal of Forest Economics, 18: 94-112. http://dx.doi.org/10.1016/j.jfe.2011.11.001

16. Marchal, R.; Mothe, F., 1994: Appreciation of Oak Wood (Quercus robur L, Quercus-petraea Liebl) for the French Consumer and Wood Professionals. Annales Des Sciences Forestieres, 51: 213-231. http://dx.doi.org/10.1051/forest:19940302.

17. Motik, D.; Kusá, A.; Jazbec, A.; Jelačić, D., 2004: Comparison of furniture demand in Croatia and Slovakia. Forest Products Journal, 54: 85-89.

18. Nicholls, D.; Bumgardner, M., 2007: Evaluating selected demographic factors related to consumer preferences for furniture from commercial and from underutilized species. Forest Products Journal, 57 (12): 79-82.

19. Nyrud, A. Q.; Roos, A.; Rødbotten, M., 2008: Product attributes affecting consumer preference for residential deck materials, Canadian Journal of Forest Research, 38 (6): 1385-1396. https://doi.org/10.1139/X07-188.

20. Oblak, L.; Barčić, A. P.; Klarić, K.; Kuzman, M. K.; Grošelj, P., 2017: Evaluation of Factors in Buying Decision Process of Furniture Consumers by Applying AHP Method. Drvna industrija, 68: 37-43. http://dx.doi.org/10.5552/drind.2017.1625.

21. Oblak, L.; Jost, M., 2011: Methodology for Studying the Ecological Quality of Furniture. Drvna industrija, 62: 171-176. http://dx.doi.org/10.5552/drind.2011.1038.

22. Oblak, L.; Kropivšek, J.; Hrovatin, J.; Zupancic, A., 2009: Analiza vplivov na nakupno odločanje pri nakupu pohištva. Les/Wood, 61: 291-296.

23. Ozanne, L. K.; Smith, P. M., 1996: Consumer segments for environmentally marketed wooden household furniture. Wood and Fiber Science, 28: 461-477.

24. Ozanne, L. K.; Vlosky, R. P., 1997: Willingness to pay for environmentally certified wood products: A consumer perspective. Forest Products Journal, 47: 39-48.

25. Pakarinen, T. J.; Asikainen, A. T., 2001: Consumer segments for wooden household furniture. Holz als Rohund Werkstoff, 59: 217-227. http://dx.doi.org/10.1007/s001070100187. 
26. Palus, H.; Mat'ova, H., 2009: End-user awareness of environmentally appropriate wood products in Slovakia. In: Proceeding of International Conference WoodEMA, University of Zagreb, Faculty of Forestry, Šibenik, Croatia, pp. 111-116.

27. Palus, H.; Parobek, J.; Kaputa, V., 2014: The role of forest certification in the european timber regulation. In: Proceedings of Scientific Papers, Position and Role of the Forest Based Sector in the Green Economy, pp. 111-117.

28. Perić, I.; Grladinović, T.; Greger, K.; Kropivšek, J., 2015: Sources of Competitiveness for Furniture Manufacturing Firms: A Review of Literature and Research Issues. In: Proceeding of International conference on wood science and technology, University of Zagreb, Faculty of Forestry, Zagreb, Croatia, pp. 179-185.

29. Ponder, N., 2013: Consumer Attitudes and Buying Behavior for Home Furniture. Mississippi State University: College of Business (online). http://www.ffi.msstate.edu/ pdf/consumer_attitudes.pdf (Accessed Sep. 21, 2019).

30. Roos, A.; Nyrud, A. Q., 2008: Preferences for pressuretreated wooden deck materials. Wood and Fiber Science, 40: 436-447.

31. Scholz, S. W.; Decker, R., 2007: Measuring the impact of wood species on consumer preferences for wooden furni- ture by means of the Analytic Hierarchy Process. Forest Products Journal, 57: 23-28.

32. Teisl, M., 2003: Eco-labeled forest products: Are consumers not listening, or are producers not communicating? Orono: University of Maine, Department of Resource Economics and Policy.

33. Troian, D., 2011: The consumer perception of design. Case study furniture sector. Trento: University of Trento.

34. Vlosky, R. P.; Ozanne, L. K.; Fontenot, R. J., 1999: A conceptual model of US consumer willingness-to-pay for environmentally certified wood products. Journal of Consumer Marketing, 16: 122-136.

http://dx.doi.org/10.1108/07363769910260498.

\section{Corresponding address:}

\section{MATEJ JOŠT, PhD}

University of Ljubljana, Biotechnical Faculty Department of Wood Science and Technology Jamnikarjeva 101

1000 Ljubljana, SLOVENIA

e-mail:matej.jost@bf.uni-lj.si 